\title{
Metóda výskumu kompozície prozaického textu v interpretačných konfrontáciách
}

\author{
Ivica Hajdučeková (Košice)
}

František Všetička: Slovesné sondy. Jinočany: H\&H, 2017. 236 s. ISBN 978-80-7319-126-9.

V slovenskej literárnej vede sa teoretické podnety z knižných titulov Kompoziciána (1986), Stavba prózy (1992), Stavba básně (1994) a i. dostali nielen do povedomia, ale aj do aktívnej výskumnej praxe vd’aka odozve $\mathrm{v}$ okruhu tzv. nitrianskej školy. Známymi sú najmä pre tých, ktorí sa venujú formálnym rozborom či štruktúrnej analýze literárnych textov. Nadväzne na predchádzajúce výsledky sa ich autor - František Všetička - v najnovšom publikačnom výstupe Slovesné sondy zameral na literárnohistorický záber na slovenskú prózu, a to s dôrazom na vývin románu. Sleduje ho od jeho vzniku v počine J. I. Bajzu v 18. storočí až po generáciu osemdesiatych rokov 20. storočia reprezentovanú tvorbou (napr.) V. Šikulu. Pri výbere textov preferuje vlastné teoretické nazeranie na ich umeleckú kvalitu, nie ustálené literárnokritické názory.

K súboru sond je priradený slovník pojmov, ktorý je aj pre zorientovaného príjemcu užitočnou pomôckou. Tak je tomu aj v prehladoch slovenskej a svetovej literatúry (v slovenskom preklade) o kompozičnej výstavbe, kedže cielene ponúkajú impulzy na rozširujúce a prehlbujúce štúdium d’alších klúčových titulov. Napokon namiesto doslovu zaradená recenzná štúdia Z. Rédeya a L. Plesníka Tuaroslovné prieniky do slovenskej prózy je priliehavým koncepčným zavíšením knižného celku, lebo do autorovho literárnovedného uvažovania vnáša nové teoreticko-kritické podnety.

F. Všetička v sedemnástich sondách do tvorby J. I. Bajzu, J. M. Hurbana, T. Vansovej, L. Podjavorinskej, M. Kukučína, M. Urbana, D. Chrobáka, M. Topol'skej, V. Šikulu, L. Balleka, S. Rakúsa, A. Chudobu, J. Puškáša a I. Hudeca - niektoré $\mathrm{z}$ nich už súborne alebo v zborníkoch a časopisoch publikované - sledoval kompozičnú výstavbu prozaických textov, ktoré sú dokladom toho, že pri kritickom prehodnocovaní umeleckých kvalít možno uplatnit nielen recepčné kritérium s tažiskom na subjektívny dojem z prečítaného, ale aj isté poetické normy, ktoré umožňujú umeleckú kvalitu textu parametrizovat' (a škálovat').

V nasledujúcich odsekoch sa pristavíme pri niektorých konkrétnych výsledkoch ponúkaných rozborov - so zameraním najmä na literatúru 19. a prvú polovicu 20. storočia - a predstavíme ich v diskurzívne ladených analyticko-interpretačných konfrontáciách.

V prvom slovenskom románe J. I. Bajzu René mládenca prihody a skúsenosti si autor všíma princíp cesty (príznačný pre osvietenskú prózu), ale aj náučnú zložku (typickú pre cestopisy), hodnotí funkciu fiktívneho rozprávača, ale aj postavu intrigána, ktorá je pre dobrodružnost neodmyslitelná, d’alej funkciu akčného incipitu, scény anagnorizy a cielené uplatnenie prosimetra. V druhej časti románu sa sústredí na nosný princíp sprievodcu a porovnáva ho s prvým českým románom od J. A. Komenského Labyrint světa a ráj srdce, pričom poukazuje na funkčné odlišnosti medzi renesančným a klasicistickým spracovaním. V rámci týchto zistení sa vynára otázka, či špecifiká sprievodcu nevedú k žánrovým obmenám pikareskného románu (princíp cesty, ako sa uvádza v slovníku pojmov, je charakteristický aj pre pikareskný román, ale tiež funkcia sprievodcu, spoločníka $\mathrm{v}$ dobrodružnom, neraz komickom putovaní). Tým by bolo možné prehodnocovat Bajzov počin aj v širších vývinových súradniciach, a to tak v dobovej európskej literatúre (napr. vo vztahu k Cervantesovmu románu), ako aj v slovenskej literatúre (postupy pikareskného románu využíval napr. 
L. N. Jégé). Výsledky rozboru teda implikujú hlbší genologický problém: žánrové varianty pikareskného románu, ktorý má v slovenskej literatúre svoju tradíciu. Aj preto možno plne súhlasit so záverom $\mathrm{F}$. Všetičku, že z vývinového hladiska sa s J. I. Bajzom spája „neobyčejně závažný románouý počin" (s. 20).

V známej historickej próze J. M. Hurbana Olejkár sa F. Všetička zameral na odhal'ovanie zložitostí kompozičnej výstavby novely s tajomstvom, aby upozornil na jej osobitosti: tajomnosṫ v introdukcii, ktorú v 11. kapitole hodnotí ako deviačný moment (aj ked' situačné zopakovanie nemusí byṫ nefunkčným vybočením, ak klimaktická dyáda anticipuje uzatvorenie príbehu s objasnením; za obdobné zvýraznenie napätia môžeme považovat aj dvojnásobné uvádzanie motta), kategóriu času s dôrazom na signifikantnost’ silvestrovskej noci (tu poznamenajme, že prechod zo starého do nového roka vo funkcii cyklického času implikuje aj iniciačný príbeh s mýtizujúcim potenciálom), charakteristiku postáv a ich zamlčané mená, na autorského rozprávača, dvojznačné (!) rekvizity s asymetrickým uplatnením v deji, ale aj na d’alšie, menej časté kompozičné osobitosti, napr. denudačnú scénu vo finále, ktorá odhaluje neočakávané tajomstvo či funkčne uplatnený numerický princíp. Niektoré Hurbanove postupy autor posudzuje v širších súvislostiach, a to na pozadí jeho novely Od Silvestra do Troch králov, ale čiastočne aj v porovnaní s románom L. N. Tolstého Knieža Strieborný. Svoje zistenia napokon uzatvára $\mathrm{v}$ prospech kontinuity tvorivého kompozičného majstrovstva J. M. Hurbana.

Obdobie realizmu, v ktorom sa intenzívne formuje tzv. anteromán (termín J. Števčeka) S. H. Vajanského, zakladajúci románovú tradíciu v slovenskej literatúre ( $\mathrm{k}$ jej počiatkom sa prirad'ujú aj romány K. Kuzmányho, L. Kubániho a i.), je zastúpené tromi autormi: T. Vansovou, v súčasnej literárnej vede už považovanou za reprezentantku neskorého biedermeieru (M. Mikulová), M. Kukučínom, ktorého ontologické kvality textu sú nanovo prehodnocované (I. Taranenková, M. Mikulová) a L. Podjavorinskou, menej pertraktovanou autorkou tzv. medzigeneračnej skupiny realistov.
V prvom slovenskom románe pre ženy Sirota Podhradských, ktorý F. Všetička zasadil v závere kapitoly do medziliterárnych vztahov v českej literatúre (B. Němcová, J. Neruda, J. Arbes), sú ocenené aj tradičné, aj netradičné prostriedky výstavby textu. Autor sa sústredil na premyslené rozvinutie kontrastného princípu medzi figurálnymi dvojicami postáv, tiež na kontrast v prostredí, ktorý sa harmonicky odreagúva v obrodzujúcej sile prírody (poznamenajme, že v priestorových súvztažnostiach je žiaduce okrem domu na Majeri a Vilinského domu s Violinou izbietkou do konfigurácie priradit aj dom Milockých), a tiež v axiologickom rozmere dobra a zla v spoločenských súvislostiach. Na margo ešte uved'me: pri uplatnení axiómy dobra a zla môžeme uvažovat aj o konfiguráciách na ženskej a mužskej osi postáv, kde krajný pól (graduálnej) škály postáv, morálne a eticky vyhranených alebo oscilujúcich, tvorí (zhýralec) Aladár Lepáry (jeho figurálnou dvojicou je intrigán Mikulčík, kým sa „neobráti“, ale prilieha k nim aj morálne upadajúci mestský švihák Bubelák), pričom centrické postavenie zastáva (hrdá a čestná) Viola, o ktorú sa však uchádza nielen Imrich Vilinský, ale aj Daniel Milocký, t. j. tvoria d’alšiu kontrastnú figurálnu dvojicu, no neopomeňme, že do triády ju dopíňa Július Vilinský, Violin ctitel', sčasti vo funkcii svorníkovej postavy (obdobne ako kňaz Silvester, ktorý má v deji funkciu spony, čomu zodpovedá aj jeho meno - nomen omen, anticipujúce zásadný axiologický obrat v deji, založený na princípe presýpacích hodín). Ďalšie uplatnenie kontrastu odhalil F. Všetička v rámcových častiach aj v názvoch kapitol a tiež v protikladných funkciách romantických rekvizít (list a úradné dokumenty), z ktorých však vyňal, a zmienku umiestnil len okrajovo do poznámky, centricky situovanú rekvizitu prsteňa, ktorá v spätosti s falošným motívom odcudzenia situačne svedčí o morálnom statuse Violy, aby sa v závere odtajnenými dokumentmi (v triáde klimaxu) potvrdil. Osobitý zretel venuje viacfunkčnému rozprávačovi a kontextovému momentu, ktoré považuje za netradičné. $\mathrm{Z}$ naznačených súvislostí sa nám však spoza dyadických kontrastov vynára 
konštrukčne náročnejší triadický princíp s graduálnym (t. j. dynamickým a škálotvorným) potenciálom. To však len potvrdzuje autorovo záverečné stanovisko o osobitých schopnostiach T. Vansovej štruktúrovał tektoniku prozaického textu.

Podobne úspešne ako T. Vansová sa ukázala aj L. Podjavorinská. Rozbor prózy Nad hrobom potvrdil to, čo si myslela dobová kritika, ked' za pseudonymom predpokladala skryté majstrovstvo M. Kukučína: išlo síce o mladú, ale mimoriadne talentovanú autorku. Svedčí o tom sujetový oblúk, využitie retrospektívy, rozvinutá temporalita, nomina propria, ale najmä metamorfný motív zvona (interpretovat ho môžeme tiež ako motív, ktorý sa podiela na sakralizácii literárnej skutočnosti, čím zvýznamňuje duchovný rozmer života a anticipuje jeho konečnú hranicu) rozvinutý do motivickej rady, ale tiež psychologické prehĺbenie v postave starého muža. Preto aj záverečné konštatovanie F. Všetičku, že ide o netradičné využitie stavebného činitela v prospech umelecky zovretého tvaru, je nanajvýš výstižné.

Zaujímavé zistenia priniesol aj pohlad na kompozíciu Kukučínovho románu Dom v stráni. Všetička poukázal na tradičné, ale aj špecifické prostriedky, ktorým doteraz literárni vedci nevenovali dostatočnú pozornost: princíp presýpacích hodín, tvoriaci podla autora sujetovú klenbu, paralelný princíp (poznamenajme, že vybudovaný na kontraste je taktiež dramatizujúcim prostriedkom podielajúcim sa na stavbe sujetovej klenby), zarámovanie, cyklický čas (tiež sujetotvorný, a to vd’aka paralele so signifikantným časom lásky, ktorá graduje na osi: zrod, kulminácia a zánik; navyše obohatený o iniciačný potenciál religiózneho času v závere, t. j. na hranici „nového života“, zakódovaného v symbolike Vel'kej noci, čím sa naznačuje - popri zákonitostiach historického vývinu v intenciách pozitivistickej teórie - aj súlad s tzv. vyšším princípom posväcovania dejín, a to aj národných). Ďalším je mystifikačný moment, ktorý nepatrí medzi tradičné stavebné prostriedky, čím autor potvrdzuje názor J. Nogeho, že Kukučín svojou tvorbou bol nielen tradicionalista, ale aj novátor.
Nie všetky uvedené zistenia F. Všetičku však možno interpretačne poňat ako konečné. Spomedzi nich sa pristavíme pri falošnom nástupe rozsiahlejšieho opisu Franićovho domu, ktorý podla Všetičku nemá, podobne ako spor Jery a Barice, s románovým dejom nič spoločné. Oba tieto úseky totiž súvisia s problematikou sociálno-spoločenského románu, a to s rodovým aspektom, ktorý má v románe (popri individuálnom príbehu lásky a národnej problematike) klúčové postavenie: úvodný opis domu (založený na numerickom princípe čísla tri), začínajúci od najstaršieho brata Iva, je totiž exponovaním aktuálneho statusu rodu, z ktorého Mate pochádza, a preto až postupne sa presúva pozornost' na najmladšieho z bratov, ktorým sa androcentrická os uzatvára. Lebo kým Franić má synov, teda pokračovatelov pretúrovského rodu (preto ani stavba jeho domu nie je ukončená), Mate má dcéry. Mateho smrt’ v závere je symbolickým uzavretím patriarchálneho spôsobu života, ale aj oslabením rodového modelu, čím sa vytvára priestor pre realizáciu nového. Do tohto androcentrického rodového zarámovania zapadá aj scéna sporu medzi ženami v rodine Mateho: konflikt Jery a nevesty Barice vyrieši až „hlava rodiny“, autorita patriarchu, ktorý ženám pripomenie hierarchické usporiadanie $\mathrm{v}$ rodine, jej subordinatívne fungovanie založené na vzájomnej zodpovednosti, čím zahatá cestu „novým poriadkom“, ktoré by do domu chcela vniest' Barica. Nakoniec $\mathrm{k}$ tomuto patriarchálnemu poriadku dospel v rámci spoločenských vrstiev aj vztah mladých dvojíc: Nika s Doricou a Katice s Paškom. Až Mateho smrt’, najmladšieho z rodu, a po nej Zandomeho činorodost je príslubom nového začiatku, časovo limitovaného „dva týždne po Velkej noci“, t. j. smerodajným je vyšší, duchovný princíp. To znamená, že hybnou silou v spoločnosti sú meniace sa hospodárske podmienky, ktoré pôsobia aj na zmeny vo funkčnosti rodového modelu, a nie svojvôla niektorého z členov rodiny (to je ústredný ideový problém, ktorý autor nastoluje a rieši aj cez lúbostný príbeh sedliačky a zemana), t. j. ustálený poriadok sveta (teofánny), v románe reflektovaný, sa tak ideovo završuje až transcendentným 
zmyslom (kristocentrizmom). Z týchto interpretačných súvislostí však vyplýva, že uvedené časti introdukcie nie sú motivicky zavádzajúce, falošné, ako by sa z formálneho hladiska zdalo.

Z tvorby medzivojnového obdobia si autor zvolil prozaikov M. Urbana a D. Chrobáka. Na Urbanovom románe Živý bič - v d’alšej štúdii aj na krátkej próze Rozprávka o Labudovi - poukazuje na umeleckú metódu príznačnú pre intenzitného autora, ktorá je blízka K. Čapkovi. Z kompozičných prostriedkov využitých v kolektivistickom románe (v slovenskej literárnej vede označovanom aj ako unanimistický) vyzdvihol napr. anticipačnú postavu, dve figurálne dvojice, ktoré sú zdrojom morfologického napätia a dôkazom tvaroslovnej virtuozity. Upozorňuje na funkciu spony v symbolike rúk, spájajúcu prvú a druhú čast̉ románu (podotknime, že založenú na významovom protiklade fatalizmus a aktivizmus; symbolika stratených rúk sa však vinie od príchodu zmrzačeného Ondreja Koreňa celou prvou častou: stratené ruky sú aj synekdochou odvedených mužov, ktorých na gazdovstve nahrádzali ženy a starci, a preto nemohúce ruky človeka sú už len paradoxným vyhrotením rezignácie), ale aj na využitie koncoviek - prevažne paralelných, už menej kontrastných - a tiež na kategóriu času, ktorý sa v zlomovej situácii vertikálne navrstvuje o sakrálny rozmer. Ten však autor nechápe ako implikáciu simultánneho diania v „rozdvojenej“ prítomnosti (princíp dyády v protiklade sakrálno - profánno), len ako lineárne oddelený polčas v sujete. Pozornost̉ venuje záverečnej scéne, v nej vizuálnemu efektu (požiar Áronovej krčmy), ktorý tu symbolicky zastupuje nielen túžbu po sociálnej spravodlivosti, ale najmä radikálnu zmenu podmienenú historickým časom vojny, ktorého dôsledky sú v symbolike obrazu živelnej skazy implicitne prítomné (ako príslub nového začiatku). Ako vyplýva z Všetičkovho porovnania s Arbesovým románom, vizuálny efekt je priam zákonitý pre tektoniku sociálneho románu. Napokon v závere autor poukázal na zhody medzi M. Urbanom a K. Čapkom, avšak následne sa odklonil od literárnych súvislostí a skízol do posudzovania ideologických problémov (etických dilem), čím sa dopustil toho istého mimoliterárneho presahu, o akom v úvode napísal: „Zejména u literárni kritiky nedopadne jeji odhad obvykle jednoznačně, vmisi se do něj světonázorové, ideologické a věroučné postoje, jež posudzovatelüm znemožňuji objektivni prístup k literárnímu dílu“ (s. 57). Preto aj porovnanie oboch autorov vyznieva v závere dost̉ rozpačito.

Posledná próza, pri ktorej sa v našich interpretačných konfrontáciách pristavíme, bude kapitola o novele D. Chrobáka Drak sa vracia. V nej totiž Všetička upriamuje pozornost̉ na literárnokritickú a teoretickú erudíciu autora, ktorý vo vývine slovenského románu a novely s tajomstvom nadviazal na tradíciu Hurbanovho Olejkára či Vansovej Siroty Podhradských. Na margo pripojme zmienku, že o snahe vytvorit prózu s tajomstvom sa D. Chrobák zdôveril v liste Š. Krčmérymu (datovanom v Prahe 24. 11. 1926) a zodpovedá tomu aj stavba próz Duo Charlie a Návrat Ondreja Balá$\check{z} a$ (obe z roku 1936). Rovnako aj Drak sa vracia (1943), pretože v nej, ako je to z literárnej histórie známe, do ideového plánu zakódoval odpoved' na vlastný príbeh - spor s J. Felixom, ktorý ho obvinil z plagiátorstva.

F. Všetička upozorňuje na niekol'ko špecifických stavebných prostriedkov, ktoré nás oprávňujú (opätovne) uznat konštrukčnú výnimočnosṫ tvorby D. Chrobáka, jeho „tvưrči metodu $s$ osobitými a do detailu promyšlenými uměleckými postupy“ (s. 80). Vyzdvihuje najmä mysterióznu postavu Draka (vymedzit ju možno aj ako mýtizovanú), ktorá svedčí nielen o dodržaní žánrovej normy novely s tajomstvom, ale aj o tažiskovom postavení tohto netradičného figurálneho typu. Všíma si temporálny moment (magickú silu svätojánskej noci), príznačný pre lyrizovanú prózu, motív kríža, ktorý je podla neho falošný, rovnako ako motívy farieb charakterizujúce kontrastný výzor figurálnej dvojice, no osobitný zretel' kladie na figurálne zarámovanie novely a funkčné postavenie epilógu. Všetička napokon konštatuje, že D. Chrobák práve týmto spôsobom komponovania prekročil limity svojej doby a stal sa jedinečným autorom štyridsiatych rokov 20. storočia v slovenskej literatúre.

Na základe analyticko-interpretačných skúseností môžeme s názorom F. Všetičku o modernej proveniencii D. Chrobáka plne súhlasit. No 
zároveň môžeme interpretačne rozvinút niektoré sémantické súvislosti: čierna a biela farba vo výzore Draka a Šimona má za úlohu podčiarknut kontrast temnoty, hriechu (konotujúci nebezpečenstvo a ohrozenie života) oproti svetlu a čistote; no náznak ambivalentnosti u Šimona ho vzápätí explicitne relativizuje (lebo kontrast je len domnelý, ked’že v tejto sujetovej línii ide o mystifikáciu Draka), a tým anticipuje premenu (dochádza k nej už v spoločnom súboji, ked' pomyselným „drakom“ sa stáva Šimon, čo sa prejaví v závere, ked’ podpáli Martinovi chalupu). Podobne aj motív (viacvýznamového) kríža v 8. kapitole viac ako utrpenie implikuje znamenie na krížnych cestách, t. j. sakralizáciu časopriestoru, kde si obaja (sokovia v láske) volia svoj „smer“ - údel, poznačený bud’ čestnostou a statočnostou, alebo ich opakom, ked'že ich úlohou nie je len priviest čriedu, ale aj pokonat sa (vo vzţahu k Eve). V závere sa mystifikácia postavy Martina Lepiša ukáže ako neodôvodnená, teda falošná, avšak znamením „draka“ je už poznačený iný - Šimon, ktorý sa voči Martinovi prehrešil (princíp presýpacích hodín). A tu sa potvrdzuje funkčnost’ epilógu: aj napriek zlyhaniu, ktoré si Šimon uvedomil (moment anagnorizy), Evinu lásku získal, a tak príbeh Draka a Šimona v prizme Evinho života je mýtom lásky a pre vnuka („len“) rozprávkou.

Zároveň sa tu však ukazuje, že na základe selektívneho prieniku do textu (formálny prístup prevažne taxatívne zhrnutý) - s dôrazom na vy- brané aspekty kompozičnej výstavby - možno poukázat v tvorivej metóde autora na niektoré konkrétne prvky ozvláštnenia, no nemožno obsiahnut', a teda ani uzatvárat' (ako napr. antiexpresionistické postupy M. Urbana v krátkej próze) tvarotvorný proces v celej jeho šírke (vo viacúrovňovej súhre formových aj obsahových zložiek kompozície), ako by sa to v komplexe náročnejšie komponovaného (a štruktúrovaného) prozaického celku žiadalo. Preto aj výsledky „sondovania“ odhalujú tvorivý potenciál autora len do istej miery.

Na záver si dovolíme uviest' názor, ktorý vyslovujeme na základe konkrétnych skúseností z analyticko-interpretačného výskumu prozaických textov, v ktorom sme sa opierali o teóriu kompozície F. Všetičku: prínosom dlhoročne overovanej koncepcie je metodicky premyslený výskumný nástroj, ktorým sa odkrýva široká škála stavebných postupov a princípov konštituujúca estetické a umelecké kvality textu. Koncepcia Všetičku má preto nesporne významný vedecký potenciál - umožňuje rozlišovat kvalitu tektoniky umeleckého textu vo viacúrovňovom tvarotvornom procese. ${ }^{1}$

1 Rozbory F. Všetičku potvrdzujú, že parametrizácia kvality umeleckého textu by sa mohla sledovat' na troch úrovniach: na úrovni narácie (problém rozprávača, dejových línií a kategórie času); na úrovni tektoniky textu (konštrukčné majstrovstvo autora, t. j. kompozičné postupy a princípy); na úrovni tvaru (semiotický proces tvarovania tzv. fikčného sveta a metaempirickej skutočnosti).

\section{doc. PaedDr. Ivica Hajdučeková, PhD.}

Katedra slovakistiky, slovanských filológií a komunikácie

Filozofická fakulta, Univerzita Pavla Jozefa Šafárika v Košiciach

Moyzesova 9, 04011 Košice, Slovensko

ivica.hajducekova@upjs.sk 